УДК 323:316.4

https://doi.org/10.34142/24130060.2019.18.2.03

\title{
ФЕНОМЕН ЕЛЕКТОРАЛЬНОГО АБСЕНТЕЇЗМУ В СУЧАСНОМУ СУСПІЛЬСТВІ
}

\author{
Н.О. Бондар \\ Харківський національний технічний університет сільського господарства \\ імені Петра Василенка
}

\section{I.B. Тодріна}

Харківський національний університет будівництва і архітектури

У статті досліджено і проаналізовано актуальні питання, пов'язані з поняттям «абсентеїзм» та його різновидами. Висвітлено питання, пов'язані з практичними причинами, які впливають на рівень абсентеїзму. Розглядається сутність абсентеїзму, ілюструються форми його проявів, аналізуються причини політичного абсентеїзму як явища. Природа абсентеїзму розкривається в статті багатоаспектно: $і$ як політична позиція індивіда (аспект індивідуального вибору), і як суспільний феномен (показник рівня залученості в політику груп населення), $і$ як неминучий елемент виборчого прочесу (причини, що перешкоджають волевиявленню громадян).

Ключові слова: абсентеїзм, виборчий прочес, політичний абсентеїзм.

\section{ФЕНОМЕН ЭЛЕКТОРАЛЬНОГО АБСЕНТЕИЗМА В СОВРЕМЕННОМ ОБЩЕСТВЕ}

\section{Н.А. Бондарь, И.В. Тодрина}

В статье исследованы и проанализированы актуальные вопросы, связанные с понятием «абсентеизм» $и$ его разновидностями. Освещены вопросы связанные с практическими причинами, которые влияют на уровень абсентеизма. Рассматривается сущность абсентеизма, иллюстрируются формы его проявления, анализируются причины политического абсентеизма как явления. Природа абсентеизма раскрывается в статье многоаспектно: и как политическая позиция индивида (аспект индивидуального выбора), и как общественный феномен (показатель уровня вовлеченности в политику групп населения), и как неизбежный элемент избирательного процесса (причины, препятствующие волеизъявлению граждан).

Ключевые слова: абсентеизм, избирательный процесс, политический абсентеизм. 


\section{THE PHENOMENON OF ELECTRICAL ABSENTEISM IN MODERN SOCIETY}

\section{N. Bondar, I. Todrina}

Article researches and analyzes actual issues associated with the concept of «absenteeism» and its varieties. Depending on the motives of non-participation in elections there are such types of absenteeism: political, economic, social, apolitical, and others. These types of absenteeism are interesting both from the theoretical and practical point of view. A clear understanding of the reasons to «ignore» election enables candidates to develop an effective strategy for the development of interest among potential voters.

The issues associated with the practical reasons that affect the level of absenteeism are high-lights. It is noted that in modern democratic countries absenteeism is quite common. The article makes a conclusion, whatever the causes of absenteeism, failure of citizens to the polls reduces the democratic potential of the society. The nature of absenteeism is revealed in the article in many aspects: both as the political position of the individual (the aspect of individual choice), and as a social phenomenon (an indicator of the level of involvement of population groups in politics), and as an inevitable element of the electoral process (reasons that impede the will of citizens).

It is proved that in modern conditions it is necessary to connect the solution of the problem of absenteeism with a more complete study and taking into account changes in the nature and status of various groups of the electorate. To solve the problem of absenteeism, a new model of the political market is also necessary, which provides for the predominance of not a community of professional politicians as a «seller» of political services, but a «buyer», that is, voters and all citizens. Such a model operates on the basis of developed feedbacks with the institutions of power and administration.

Key words: absenteeism, electoral process, political absenteeism.

Постановка проблеми. На сьогодні абсентеїзм - ухилення виборців від участі у виборах до органів державної влади і місцевого самоврядування - набув характеру системного елемента політичного процесу у більшості країн світу. У кожній країні цей процес протікає в різних умовах і приймає різні форми. При цьому якщо в західній науковій літературі абсентеїзм розглядається здебільшого як девіантна форма політичної поведінки раціонального виборця, то вітчизняні науковці розглядають його або як результат свідомого політичного вибору, або в контексті недорозвиненості політичної культури українських громадян.

Аналіз актуальних досліджень. У сучасній науковій літературі знайшли відображення різні аспекти абсентеїзму. Класичні моделі впливу соціально-групових конфліктів на ідеологічну партійну диференціацію, що послужили основою для сучасного аналізу абсентеїзму, були закладені в 
працях С. Ліпсета i C. Роккана. Істотний внесок у розробку проблеми абсентеїзму внесли П. Лазарсфельд, Б. Берельсон, В. Макфол, Р. Росс, а також соціологи мічиганської школи: В. Глазер, В. Міллер, Р. Купер, П. Конверс, А. Вулф, А. Кемпбелл.

Мета статті полягає в комплексному аналізі причин, проявів i можливих шляхів подолання та зменшення масштабів абсентеїзму як явища в контексті сучасних соціально-політичних процесів і трансформацій.

Виклад основного матеріалу. Абсентеїзм розуміється як політична позиція індивіда (аспект індивідуального вибору), як суспільний феномен (показник рівня залученості в політику груп населення) (Инглхарт, 1997) і як елемент виборчого процесу (в контексті вивчення причин, що перешкоджають волевиявленню громадян) (Lasarsfeld, Berelson \& Gaudet, 1948).

При цьому необхідно виділити основні причини зростання числа тих, хто ухиляється від участі у виборах. До числа цих причин, на наш погляд, відносяться, перш за все, вплив масової культури і суспільства споживання, постмодерністський дискурс і практики (Денисенко, 2015), криза ліберальної демократії, криза політичного ринку, загальна деградація політики і зниження якості еліт.

3 точки зору політичної мотивації можна виділити і описати кілька можливих типів абсентеїзму:

- аполітичний - пов’язаний із принциповою неучастю особистості в політиці, відсутністю інтересу до неї;

- протестний - обумовлений неприйняттям потенційним виборцем чинної влади і їі політики;

- $\quad$ опортуністичний - своєрідний «торг» виборців 3 політичною системою 3 підвищенням «ставок» (прийняти участь у голосуванні тільки в обмін на політичні рішення і зміни в політиці влади, які влаштовують даного виборця); 
- конформістський - неявка на виборчі дільниці внаслідок некритичного прийняття особистостями і групами чинної влади і їі політики по всіх основних питаннях, які роблять голосування таких виборців «зайвими» в їх власних очах;

- абсентеїзм, пов’язаний $з$ так званою «кризою проникнення» - коли імпульси, що генеруються політичною системою і владою, не доходять до виборця через ряд блокуючих ефектів (недовіру, слабкість механізмів зворотного зв’язку, що спотворює реальність вплив ЗМІ) (Вершина та Михайлюк, 2002), в результаті чого виборець втрачає політичну орієнтацію і здатність до раціонального вибору.

Абсентеїзм може бути розглянутий у всьому різноманітті своїх проявів. По-перше, як особливий тип політичної поведінки. Останній пов’язаний 3 послідовним ухиленням від реалізації виборчих прав, 3 особистою мотивацією (протестною або знеособлено-конформістською). При цьому ухилення від участі у виборах далеко не завжди є наслідком аполітичної позиції (Бучин та Кулеба, 2011).

По-друге, як прояв політичного вибору (як складової частини «суспільного вибору»). Причому даний вибір, здійснений у формі відмови від голосування, може виявитися як на користь статус-кво (існуючого стану справ в політиці), так і на користь змін (як прояв відмови від підтримки влади та іiі політики через відмову від участі у виборах). Тому абсентеїзм далеко не рівнозначний підтримці чинної влади і їі політики «мовчазною більшістю», i за ним може ховатися масштабне відторгнення певною частиною електорату політичних реалій.

По-третє, як демонстрація суспільного відношення до політики влади і існуючої політичної системи. I ставлення, виражене шляхом відмови від участі у виборах, може розглядатися як своєрідний бойкот («мовчазний референдум зі знаком мінус») політичного курсу та результатів правління чинної влади. 
По-четверте, як спосіб ухилення від політики і засіб деполітизації суспільства («експансія приватного»). Постіндустріальне суспільство масового споживання, як відомо, перешкоджає політичній консолідації і мобілізації, стверджуючи пріоритет приватного життя і приватних інтересів на противагу громадському обов’язку і громадським інтересам (Воронянський, 2014). У результаті ставиться під сумнів не тільки електоральна участь, а й саме існування даного суспільства як політичного цілого.

По-п’яте, як особливий тип і стратегія політичного торгу. Суспільство в особі певної частини своїх представників «підвищує ставки» в процесі неформального «торгу» 3 можновладцями, домагаючись від них коригування політики в бік більшої гнучкості й більшої обліку інтересів різних соціальних груп.

По-шосте, як результат кризової ситуації на політичному ринку, яка проявляється в глибокому (а іноді і зовсім катастрофічному) розриві між політичним попитом і політичною пропозицією (Воронянський, 2012b) i може виступати відповіддю на відсутність реальної політичної альтернативи (дефіцит альтернатив) i монополізацію політики i влади певними політичними силами.

По-сьоме, як прояв кризи громадянської свідомості та інститутів громадянського суспільства. Громадянське суспільство i його інститути, перебуваючи в стані тривалої депривації і відчуження, може відповісти на них відмовою від участі у виборах як важливої складової частини політики (в перспективі це загрожує делігітімацією політичної системи як крайнього варіанту розвитку подій).

3 точки зору концептуалізації причин і витоків феномена абсентеїзму, на наш погляд, доцільно виділити наступні підходи.

Пояснення абсентеїзму з позицій електоральної і політичної культури як наслідку іï глибокої трансформації або деградації в результаті більш 
загальної кризи політики (i розпаду усталеного «політичного поля» 3 властивими йому законами) (Денисенко, 2013).

3 позицій електоральної та політичної поведінки - як специфічної моделі поведінки, породженої внутрішніми мотивами, інтересами і логікою окремо взятих індивідів.

3 інституційної точки зору - як реакція суспільства на кризу електоральних і в цілому демократичних інститутів, що виражається в неприйнятті правил і норм, відтворюваних за допомогою цих інститутів, одним з яких і $є$ інститут виборів, що піддається в цьому випадку глибокій депривації й характеризується наростаючою дисфункціональністю, тобто нездатністю виконувати звичні політичні функції (Воронянський, 2012c).

3 точки зору теорії політичних конфліктів і криз - як наслідок «кризи участі» i «кризи проникнення», що стали наслідком наростаючого політичного відчуження в конкретному суспільстві.

3 позицій теорії «суспільного вибору» і неоінституціоналізму - як прояв специфічного різновиду опортуністичного поведінки (тобто поведінки, націленої на задоволення індивідуальних інтересів на шкоду міркувань «громадського обов’язку» в ситуації, коли суспільство з різних причин не може запропонувати своїм членам вигідних альтернатив у широкому розумінні і розрізнені політичні суб’єкти реалізують власні соціальні та політичні стратегії, націлені на короткострокову вигоду) (Воронянський, 2012а). Участь у виборах в подібній ситуації розглядається ними як «невиправдана трата власного часу і зусиль».

3 позицій теорії політичного ринку - як наслідок розбіжності «Політичного попиту і політичної пропозиції». У політиці можливі ситуації, коли чинній владі, політичній еліті («політичному класу») нічого запропонувати суспільству в відповідь на його зростаючі вимоги i невдоволення (Воронянський, 2014). У цій ситуації громадяни як споживачі «політичних послуг» можуть висловити своє невдоволення ситуацією, що склалася, в формі відмови від голосування на виборах. 
На наш погляд, абсентеїзм - це комплексне політичне явище, породжене глибокими змінами в змісті, сенсі і характері політичного розвитку і політики на рубежі XX-XXI ст. В сучасних умовах частина держави залишається в стані модерну, але інша частина змінюється в напрямку більшої фрагментації, зменшення уніфікації, коли іiі автономія ставиться під сумнів (Денисенко, 2015b). В результаті сучасна держава скоріше нагадує ослаблену численними «проникненнями» $\mathrm{i}$ «вторгненнями» в простір іiі інтересів і компетенції конструкцію, ніж сильну і монолітну організацію і суб’єкта консолідованої політичної дії.

Які ж власне політичні наслідки перерахованих змін? Політика відтепер не пов’язана зі звичним функціонуванням держави і політичної системи, з централізованим («провіденціальним») формуванням політичних смислів, норм і цінностей політичної культури (Денисенко, 2015а). Фактично в сучасних постіндустріальних суспільствах приватні інтереси перемогли соціально-групову політичну самоідентифікацію, тому політика просто не входить до переліку усвідомлених інтересів більшості населення. Криза централізовано-бюрократичних держав і усталених форм державної влади генерує, в свою чергу, не менш масштабні і гострі кризи:

- $\quad$ довіри до сфери політики та їі базових інститутів;

- легітимності політичних і державних інститутів, а також заснованого на них політичного порядку в цілому;

- проникнення (пов’язана 3 низькою якістю реалізації прийнятих державних рішень, 3 порушеною роботою механізму зворотного зв’язку).

Компенсувати ці кризи нинішнім політичним системам, навіть цілком демократичним, так і не вдалося.

У наявності і очевидне збільшення ролі та ваги маніпуляційної складової сучасних технологій, що викликає цілком очевидну негативну реакцію на них суспільства, що поширюється і на сам інститут виборів. Феномен політичної і пропагандистської плутократії став сьогодні глибоко 
вкоріненою політичною реальністю, охопивши своїм впливом і сам інститут виборів. Знайти надійну противагу експансії цих явищ сучасному суспільству поки не вдається, що відбивається на загальному зниженні популярності виборів і виборчого процесу як одного 3 ключових елементів сучасної демократії.

Висновки та перспективи подальших досліджень. Підхід до вирішення проблеми абсентеїзму, на наш погляд, повинен мати комплексний характер. Не слід зводити їі рішення до простого вдосконалення виборчого законодавства i виборчих технологій, оскільки електоральні практики нерозривно пов’язані 3 більш загальними соціальними практиками. Чи містить однозначне рішення заявленої нами проблеми просте? Посилення механізмів «прямої демократії», покликане повернути довіру виборців до демократичних процедур, у реальному політичному житті неминуче стикається з низкою обмежень, які відзначалися ще класиками соціологічної і політичної науки (Lipset \& Rokkan, 1990, p. 91-111).

На наше переконання, в сучасних умовах слід пов’язувати вирішення проблеми абсентеїзму з більш повним вивченням та урахуванням змін в природі i статусі різних груп електорату. Аби вирішити проблеми абсентеїзму, необхідна і нова модель політичного ринку, яка передбачає переважання на ньому не спільноти професійних політиків як «продавця» політичних послуг, а «покупця», тобто виборців і всіх громадян. Така модель діє на основі розвинених зворотних зв’язків з інститутами влади і управління.

Необхідні й нові політичні та електоральні інститути - більш гнучкі і адаптовані до запитів виборців і всіх громадян. Це передбачає також розвиток нової електоральної культури, заснована на почутті взаємної відповідальності політичних інститутів суспільства і громадян.

\section{ЛІТЕРАТУРА}

1. Бучин, М. та Кулеба, О., 2011. Абсентеїзм як форма низької політичної участі. Українська начіональна ідея: реалї та перспективи розвитку, 23, с. 98-102. 
2. Вершина, В. А. та Михайлюк, А. В., 2002. О карнавальных истоках современной цивилизации. Докса: зб. наук. праць з філософії та філології, 2, с. 124-132.

3. Воронянський, О., 2012а. Національна еліта сучасної України: проблема визначення. Українознавчий альманах, 8, с. 205-207.

4. Воронянський, О. В., 2012b. Політична трансформація в контексті проблеми перерозподілу ресурсів. Вісник Харківського національного університету імені В.Н. Каразіна. Серія: Питання політології, 20 (1007), с. 51-57.

5. Воронянський, О. В., 2014. Політичні інститути: механізм формування в конкурентному середовищі. Сучасне суспільство: політичні науки, соціологічні науки, культурологічні науки, 1(5), с. 15-28.

6. Воронянський, О. В., 2012с. Роль національного суверенітету в легітимації державної влади. Актуальні проблеми державного управління, 2, с. 216-221.

7. Денисенко, І. Д., 2015а. Моделювання поведінки особистості в сучасних соціокультурних контекстах: методологічні засади та перспективи. Науковий вісник. Серія «Філософія», 45 (частина I), с. 205-214.

8. Денисенко, І. Д., 2013. Соціальні мережі в контексті соціокультурного підходу: евристичний потенціал дослідження. Вісник ХНПУ імені Г.С. Сковороди «Філософія», 40, с. 22-28.

9. Денисенко, I. Д., 2015b. Теорія соціального простору: евристичний потенціал щодо соціально-політичних досліджень. Сучасне суспільство: політичні науки, соиіологічні науки, культурологічні науки, 2(10), с. 27-37.

10. Инглхарт, Р., 1997. Постмодерн: меняющиеся ценности и изменяющиеся общества. Политические исследования, 4, с. 6-32.

11. Lipset, S. M. \& Rokkan S., 1990. Cleavage Structures, Party Systems, and Voter Alignments. The West European Party System.

12. Lasarsfeld, P. F., Berelson, B. R. \& Gaudet, H., 1948. The People's Choice. How the Voter Makes up his Mind in a Presidential Campaign.

\section{Інформація про автора}

Бондар Наталія Олександрівна - кандидат історичних наук, доцент кафедри ЮНЕСКО «Філософія людського спілкування» та соціально-гуманітарних дисциплін Харківського національного технічного університету сільського господарства імені Петра Василенка; еmail: nbon79@gmail.com; ORCID: http://orcid.org/0000-0003-3449-5884.

Тодріна Інна Валеріївна - кандидат економічних наук, доцент, доцент кафедри економічної теорії Харківського національного університету будівництва та архітектури; e-mail: todrina.innochka@gmail.com; ORCID: http://orcid.org/0000-0003-1381-3281.

Стаття надійшла до редакції: 18.02.2019 р. $\quad$ Прийнята до друку: 28.02.2019 p. 